\title{
Solid state anaerobic digestion of mixed organic waste: the synergistic effect of food waste addition on the destruction of paper and
} cardboard

\author{
Nigel G. H. Guilford ${ }^{1,}{ }^{*}$, HyunWoo Peter Lee ${ }^{1}$, Kärt Kanger ${ }^{1,2}$, Torsten Meyer ${ }^{1}$, and \\ Elizabeth A. Edwards ${ }^{1, *}$
}

${ }^{1}$ Department of Chemical Engineering and Applied Chemistry and BioZone, University of Toronto, 200

College Street, Toronto, Ontario, Canada, M5S 3E5

${ }^{2}$ Faculty of Science and Technology, University of Tartu, Tartu, Estonia

*Corresponding authors: NGH Guilford and EA Edwards

Address correspondence to:

Elizabeth A. Edwards: elizabeth.edwards@utoronto.ca

Nigel Guilford: nigel.guilford@utoronto.ca

Short title: Solid state anaerobic digestion of mixed organic waste

Keywords: Anaerobic digestion, organic fraction municipal solid waste, food waste, lignocellulosic fibres 
bioRxiv preprint doi: https://doi.org/10.1101/564203; this version posted February 28, 2019. The copyright holder for this preprint (which was not certified by peer review) is the author/funder, who has granted bioRxiv a license to display the preprint in perpetuity. It is made available under aCC-BY-NC-ND 4.0 International license.

Table of Contents (TOC)/Abstract Art:

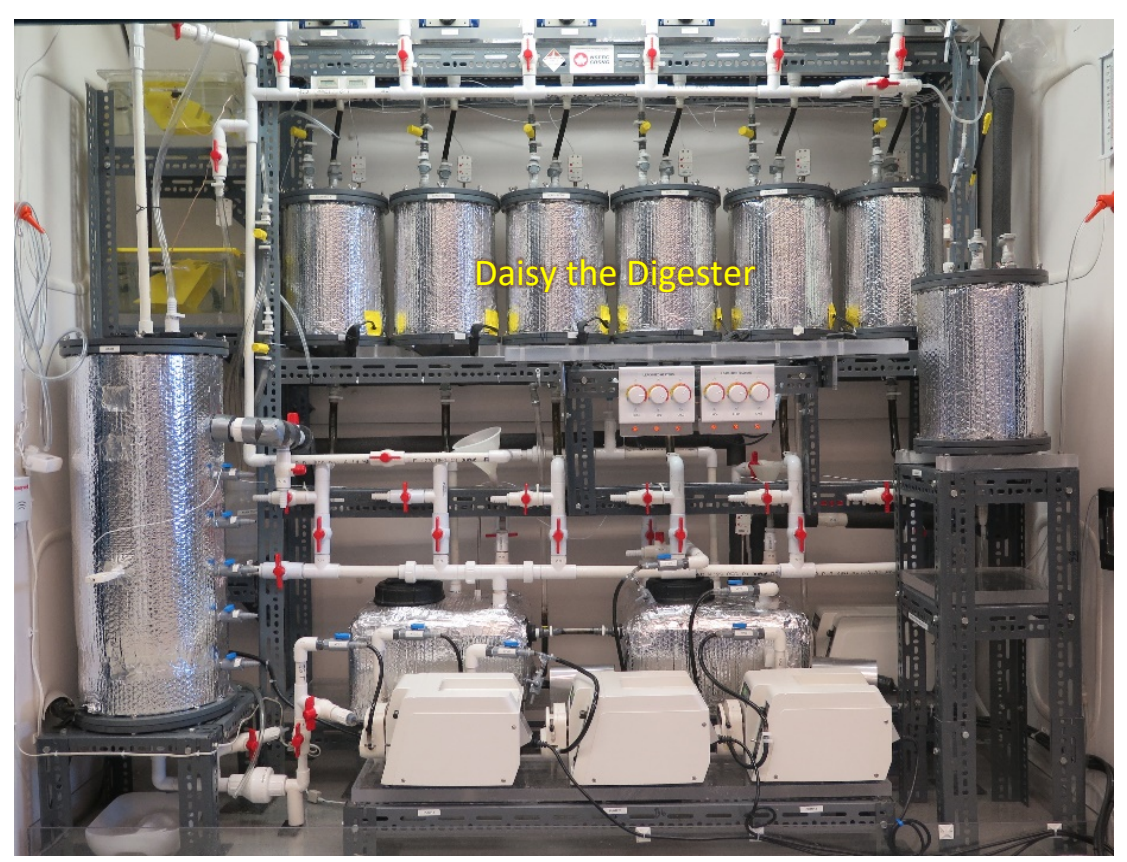




\section{ABSTRACT}

2 Full-scale anaerobic digestion processes for organic solid waste are common in Europe, but generally

3 unaffordable in Canada and the United States because of inadequate regulations to restrict cheaper

4 forms of disposal, particularly landfill. We investigated the viability of solid-state anaerobic digestion

5 (SS-AD) as an alternative that reduces the costs of waste pretreatment and subsequent wastewater treatment. A laboratory SS-AD digester, comprising six 10L leach beds and an upflow anaerobic sludge

7 blanket reactor treating the leachate, was operated continuously for 88 weeks, with a mass balance of

$8101 \pm 2 \%$. The feed was a mixture of cardboard, boxboard, newsprint, and fine paper, and varying

9 amounts of food waste (from 0\% to $29 \%$ on a COD basis). No process upset or instability was observed.

10 The addition of food waste showed a synergistic effect, raising $\mathrm{CH}_{4}$ production from the fibre mixture

11 from 52.7 L.kg-1 COD fibreadded to $152 \mathrm{L.kg}^{-1} \mathrm{COD}$ fibreadded, an increase of $190 \%$. Substrate COD destruction

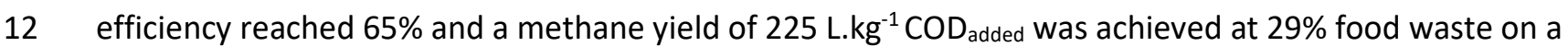

13 COD basis, and a solids retention time of 42 days. This performance was similar to that of a completely

14 stirred tank reactor digesting similar wastes, but with much lower energy input.

\section{INTRODUCTION}

17 Anaerobic digestion (AD) is a well-established method for the treatment of organic solid waste and the 18 production of renewable energy. In a comparative study, Hodge et al. (2016) concluded that, among composting, landfilling, combustion with energy recovery and AD, a combination of $A D$ and landfill was

20 the leading alternative in terms of lowering global warming potential. Solid organic waste is

21 heterogeneous, variable and complex. Consequently, conventional anaerobic digesters (De Baere \&

22 Mattheeuws, 2013; Guilford, 2009) must be preceded by extensive pretreatment, such as sorting, size

23 reduction, contaminant removal, and water addition, to render the feedstock suitable for processing, all 24 of which add significantly to the cost. 
26 The Landfill Directive of the European Union (1999) restricts the disposal of organic wastes, and has

27 driven the widespread adoption of more expensive waste processing technologies, particularly anaerobic digestion. Canada and the United States lack similar, overarching, regulations; consequently, anaerobic digestion is common in Europe and relatively rare in North America. As a direct result, in Canada, most organic waste (about 10 million tonnes per year (Government of Canada, 2015) consisting of about $38 \%$ food waste $62 \%$ paper and cardboard (City of Ottawa, 2007; Government of Ontario, 2004 ) is still disposed of in landfills which, in the aggregate, generate about 20 million tonnes per year of greenhouse gases ( $\mathrm{CO}_{2}$ eq.) (Environment Canada, 2017); furthermore, a source of renewable energy is largely forgone. Satchwell et al. (2018) note the advantages of solid-state anaerobic digestion (SS-AD), including less pretreatment and reduced wastewater treatment, but identify numerous scientific, operational, and policy challenges limiting its wider adoption in the United States and Canada.

In an attempt to circumvent the lack of strong regulations, or incentives, in North America (Guilford, 2017), a new approach to AD was developed and patented to treat all forms of solid organic waste from residential and commercial sources (Forrestal et al., 2006a; Forrestal et al., 2006b). The underlying

41 principle, derived from bioreactor landfill practices, is to accommodate the properties of the waste as-

42 received as far as possible. The process employs SS-AD; the waste remains stationary, and the leachate generated by its degradation is recirculated through the waste. Biogas is recovered and put to beneficial

44 use, and the digestate remaining is aerobically cured and turned into compost. It is designed to accommodate the complex properties of solid waste with minimal pretreatment, with the ultimate goal

46 of being cost-competitive with landfill; initial estimates suggested that this can be achieved (Guilford,

47 2009). In exchange for simplicity of design, some trade-offs were expected. For example, it was assumed 
(SRT), and a larger physical footprint required (compared to, for example, a CSTR), but that capital and

50

51

52

53

54

55

56

57 operating costs would be lower.

The AD technologies commonly applied to solid waste employ various configurations and operating conditions (De Baere \& Mattheeuws, 2013). The majority are single stage, and either plug flow or CSTRs, operating at $38^{\circ} \mathrm{C}$ or $55^{\circ} \mathrm{C}$. They digest primarily food waste $(\mathrm{FW})$ and the organic fraction of municipal solid waste (OFMSW), plus some leaf and yard waste in some cases. Consequently, most of the research on the AD of organic solid waste uses FW or OFMSW as the substrate. Zhang et al. (2012) measured the digestibility of OFMSW in a CSTR, giving $62 \%$ substrate destruction as volatile solids (VS) and yielding $304 \mathrm{~L} \mathrm{CH}_{4} / \mathrm{kg} \mathrm{VS}_{\text {added; }}$ Browne et al. (2013a; 2013b; 2014) tested a two-stage digester comprising leach beds (LBs) and upflow anaerobic sludge blanket (UASB), giving 75\% substrate destruction as VS digesting OFMSW and yielding $384 \mathrm{~L} \mathrm{CH}_{4} / \mathrm{kg} \mathrm{VS}_{\text {added, }}$, but experienced serious problems with hydraulic conductivity, ammonia inhibition, and volatile fatty acid (VFA) inhibition. Though lignocellulosic fibers make up a high proportion of solid organic waste, only a very few studies have examined the digestibility of these substrates (Di Maria et al., 2017; Eleazer et al., 1997; Pommier et al., 2010; Yuan et al., 2012; Yuan et al., 2014). These previous experiments are summarized in Results and Discussion, Section 3.8.

To evaluate the effectiveness of SS-AD, we designed and built Daisy the Digester, a lab-scale version of the new SS-AD digester design (Guilford, 2009), a hybrid system combining the robustness and simplicity of a landfill bioreactor with the benefits of multi-stage digestion. Daisy comprises six sequentially-fed leach beds, an upflow anaerobic sludge blanket (UASB) and two tanks, plus ancillary components and a control system. We also designed a feed stream composed of a mixture of cardboard (CB), boxboard (BB), newsprint (NP) and fine paper (FP), collectively representing the fibre fraction (FB), plus varying amounts of food waste, to simulate the range of composition of industrial, commercial and institutional 
waste (IC\&I) (Government of Canada, 2010). In order to maintain permeability, shredded ash wood was added as a bulking agent (BA). The objectives of the research were to measure process stability and digester performance (methane yield and substrate destruction efficiency) in response to variations in the proportion of food waste added, for comparison with more conventional CSTR-type wet digesters processing similar wastes. As a result of extensive careful and frequent monitoring of the system, the mass balance over the entire 88-week experiment was nearly perfectly conserved, revealing a remarkably strong effect of food waste on the extent of digestion of the fiber fraction.

\section{MATERIALS AND METHODS}

\subsection{Daisy the Digester - Design}

83 The design is derived from bioreactor landfill practice, in which leachate recirculation accelerates the

84 decomposition of unsorted solid waste (Guilford, 2009). Daisy comprises six 10L leach beds (8.5L working volume), a UASB (27.5L working volume), a UASB feed tank (Tank 1 ) and a leach bed feed tank (Tank 2) (17.5L working volume each), three peristaltic pumps (P1, P2, and P3) and two wet-tip gas meters (GM1 and GM2) to measure biogas volumes produced (Fig. 1). The tanks and the UASB are heated automatically with self-regulating heat tape; each has a programmable thermostatic controller; the LBs have manually controlled heaters. The frequency and volume of leachate delivered to the leach beds is controlled automatically with a programmable logic controller (PLC); leachate is recirculated from Tank 2, via P3, through the upper manifold, and back to Tank 2. Periodically, the automatic valves, controlled by the PLC, open in sequence and redirect the flow to each leach bed in turn. The cycle repeats continuously. Leachate drains from each leach bed to a common manifold and into Tank 1; it is then transferred by $\mathrm{P} 1$, via a clarifier within the tank, to the UASB. Effluent from the UASB is discharged to Tank 2. The hydraulic balance between Tank 1 and Tank 2 is maintained by P2 and an overflow pipe 
GM1, and the aggregated biogas from six LBs and two tanks is discharged through GM2. Daisy runs at a slight positive pressure of $1.2 \mathrm{kPa}$, generated by $12 \mathrm{~cm}$ water column in gas meters. Fig $1 \mathrm{~B}$ shows 9 liquid sampling valves; V2 (UASB feed) was used for all the samples reported here; the balance were used in a companion study (Lee, 2018) intended for publication at a later date. The design basis, construction, and operation of Daisy are described in much greater detail elsewhere (Guilford, 2017).

\subsection{Operational set-up of Daisy}

104 Daisy operated as a sequentially-fed batch reactor with a fresh LB of waste (containing 1.2 to $1.7 \mathrm{~kg}$ of 105 substrate as COD) added once per week, replacing a 6-week old leach bed that was removed for analysis. As depicted in Fig. 1B, LB 1 is due for replacement after an SRT of 42 days. The UASB and Tank 1 were set at $37^{\circ} \mathrm{C}$; Tank 2 was set at $39^{\circ} \mathrm{C}$ (this was to provide additional heat to the LBs, before they were equipped with manual heaters at week 25). The leachate recirculation rate remained constant throughout at $565 \mathrm{~mL}$ per LB, every 30 minutes. This value was derived from Murto et al. (2013) who reported a flowrate of $16.5 \mathrm{~L} . \mathrm{min}^{-1}$ in a $5.2 \mathrm{~m}^{3}$ leach bed containing $3.4 \mathrm{t}$ of waste plus $2.6 \mathrm{~m}^{3}$ of water, or $2.8 \mathrm{t}$ of a mixture of waste and bulking agent plus $2.6 \mathrm{~m}^{3}$ of water. The UASB was fed at $125 \mathrm{~mL} \cdot \mathrm{min}^{-1}$

112 giving a hydraulic retention time (HRT) of 3.6h and an upflow velocity $\left(\mathrm{V}_{\text {up }}\right)$ of $0.5 \mathrm{~m} . \mathrm{h}^{-1}$. The peristaltic

113 pumps were calibrated with and without a $1.3 \mathrm{~m}$ head, with new tubing and with worn tubing (Norprene

114 A-60-G); the calibration remained unchanged. The wet tip meters (GM1 and GM2), supplied by Archaea

115 Press, were calibrated using a continuous water-displacement method (Guilford, 2017); biogas production (100mL/tip) was recorded in the datalogger every 5 minutes and also every hour.

117 Temperature was recorded every 15 minutes (six LBs, two tanks, GM2 and the UASB). Biogas volumes 118 were corrected to STP using the recorded temperature inside GM2, and the barometric pressure was recorded by a weather station located on the roof of the building. 


\section{$121 \quad 2.3 \quad$ Feedstock and digestate - preparation, sampling and analysis}

122 All components of the feedstock were recovered from residential waste recycling programs and

123 prepared as follows. The CB and BB were coarsely shredded $(<3 \mathrm{~cm} \times 4 \mathrm{~cm})$; the FP and NP were shredded

124 in an office shredder $(<5 \mathrm{~cm} \times 0.5 \mathrm{~cm})$; the BA, consisting of prepared ash wood, was supplied in 6

125 batches (BA\#1 to BA\#6). BA\#5 was processed through a chipper; the other five were shredded in a Roto-

126 Chopper and screened to $<5 \mathrm{~cm}$; all were stored in bulk. The FW was recovered from a residential green

127 bin program in the Region of Durham, Ontario (which prohibits sanitary products and non-compostable

128 plastic). It was presorted to remove plastic and larger junk, shredded to $<10 \mathrm{~cm}$ in a shear shredder, and

129 stored in sealed plastic bags $\left(\sim 1.5 \mathrm{~kg}\right.$ ea.) at $-20^{\circ} \mathrm{C}$.

131 The FW was thawed as needed, and hand-sorted to remove bones, inorganic matter, and smaller foreign

132 objects; it was either fed directly to Daisy (weeks 12 to 76), or first pulped in a blender with an equal

133 quantity of water (weeks 1 to 11 and 77 to 88 ). The fibres (FB) and BA were weighed, and mixed dry, in a

$13420 \mathrm{~L}$ bucket using large stainless-steel spoons. Water was added to saturate the fibres (between 3.8L and

$1353.2 \mathrm{~L}$ depending on the amount of food waste added); the FW was added last and thoroughly mixed in

136 using the same method.

138 To measure the digestibility of individual components of the feed, at different levels of FW addition

139 under actual digester conditions, stainless steel tea balls or 'coupons' (Fig. S1), were filled with samples

140 of a single fibre (between 1 and $4 \mathrm{~g}$ ), and inserted into the waste. Thus, at any given moment, four of the

141 LBs each contained six $2.5 \mathrm{~cm}$ tea balls comprising two triplicate sets; for example, three of CB and three

142 of NP, or three of BB and three of FP. The other two LBs each contained a single $5 \mathrm{~cm}$ tea ball containing

143 a sample of BA (7 to $11 \mathrm{~g})$; the larger size was necessitated by the morphology of the BA. 
Each week fresh waste (feed) was placed into a LB, tamped down by hand, the head space measured, the lid installed, and the assembly flushed, leak tested, and pressurized to $50 \mathrm{~cm}$ water column (WC), with argon, before installation in Daisy. Quick-disconnect fittings with shut-off valves enabled rapid LB removal and replacement without ingress of air. At the end of each digestion period (typically 6 weeks), a LB was removed and replaced with a LB of fresh waste. After removal, each LB was drained for $24 \mathrm{~h}$, and the recovered leachate returned to Tank 1 (through a valved port to preserve gas pressure). The

151 headspace was re-measured and the settlement noted. The coupons were removed and weighed and

152 their TS/VS determined using standard methods; $50 \mathrm{~mL}$ samples of the digestate (DG) were taken from $15313,20,25$ and $28 \mathrm{~cm}$ from the top of the LB, for determination of TS/VS; a separate sample (also taken 154 at $25 \mathrm{~cm}$ ) was analyzed for COD. A $300 \mathrm{~g}$ bulk sample of DG was retained and frozen at $-20^{\circ} \mathrm{C}$. A detailed 155 record of the input and output for every LB was maintained. An example is shown in Table S1.

\subsection{Experimental Design}

The 88-week experiment was divided into 12 periods, each representing a different set of operating conditions (Table 1). After initial start-up, which took 5 weeks, the impact of specific process changes was investigated. In Period 1 (weeks 6 to 15) consistent operation was established. The solids retention time (SRT) was always set at 42d except during Period 2 (weeks 16 to 24 ) which briefly explored an increase in SRT to 49d (7 weeks) by omitting LB replacement every 6th week; in Period 3 Daisy was returned to $42 \mathrm{~d}$ ( 6 week) SRT; $\mathrm{COD}_{\mathrm{FW}}$ addition was $17.2 \%$ throughout Periods 1,2 and 3 . In Periods 4a, was returned to $17.2 \%$ in a single step; a change to a new batch of bulking agent at week 58 caused a

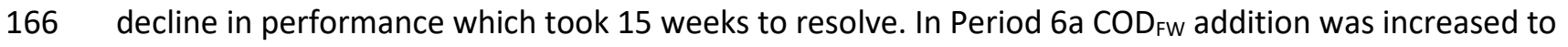
$167 \quad 21.2 \%$ and in Period $6 b$ to $29.3 \%$. 


\subsection{Sampling and Analytical Methods}

170 The sampling, analytical and data management methods used are summarized below; a more detailed

171 description is provided in the Supporting Information (SI). The elemental composition of each individual

172 component of the feedstock was determined using a Thermoflash $2000 \mathrm{CHN}$ analyzer; TKN was also

173 measured to achieve greater precision for nitrogen. Total solids (TS), volatile solids (VS) and chemical

174 oxygen demand (COD) were measured using standard methods (APHA, 1992); VS was used for

175 comparison with published results, COD measurements formed the basis of the mass balance

176 calculation. The COD content of all feedstocks was also calculated from their elemental composition, for

177 comparison to the measured values.

179 Four leachate samples were withdrawn from valve V2 (Fig. 1B) four times per week. One (15 mL) was

180 analyzed for TS, VS, and COD using standard methods (APHA 92); the second (50 $\mathrm{mL}$ ) to determine the

$181 \mathrm{pH}$ and alkalinity ratio, the third $(2 \times 10 \mathrm{~mL})$ was prepared and stored for subsequent microbial analysis

182 and the fourth $(10 \mathrm{~mL})$ was filtered using $0.22 \mu \mathrm{m}$ nylon syringe filter and stored at $-20^{\circ} \mathrm{C}$ for subsequent

183 ion chromatography (IC) analysis for VFAs and sulphate. Sampling for VFA and microbial analysis began

184 at week 35. Approximately every two weeks, samples of biogas $(200 \mu \mathrm{L})$ were extracted through septa,

185 installed in the infeed lines to $\mathrm{GM} 1$ and $\mathrm{GM} 2$, and analyzed for $\mathrm{CH}_{4}$ and $\mathrm{CO}_{2}$ using a gas chromatograph

186 with a thermal conductivity detector (GC-TCD). Temperatures and biogas volumes were recorded in the

187 data logger and downloaded daily. A daily activity log was maintained to record all inputs and outputs

188 (time, type and volume), system adjustments, operating anomalies, and corrective measures. 


\subsection{Calculations}

191 The stoichiometric formula of the substrates $C_{n} H_{a} O_{b} N_{c}$, and the stoichiometry of digestion, were

192 calculated from elemental analysis of the weighted average composition of the substrates fed to Daisy

193 (weeks 6 to 88 inclusive) using Equations (1-4) (Rittmann \& McCarty, 2001).

$$
C_{n} H_{a} O_{b} N_{c}+\frac{(2 n+0.5 a-1.5 c-b)}{2} O_{2} \rightarrow n C O_{2}+c N H_{3}+\frac{a-3 c}{2} H_{2} 0
$$

195

where:

$$
\frac{C O D}{M a s s}=\frac{2 n+0.5 a-1.5 c-b 16}{12 n+a+16 b+14 c}
$$

where:

$$
\begin{aligned}
& n=\frac{\% C}{12 T}, a=\frac{\% H}{T}, b=\frac{\% O}{16 T}, \text { and } c=\frac{\% N}{14 T} \\
& T=\% \frac{C}{12}+\% H+\% \frac{O}{16}+\% \frac{N}{14}
\end{aligned}
$$

The $\mathrm{C}: \mathrm{N}$ ratio was calculated from:

$$
C: N \text { ratio }=\frac{\% C}{12} / \frac{\% N}{14}
$$

The mass balance (on a COD basis) was calculated in two ways, Method A: (methane + new biomass)/

$\mathrm{COD}_{\text {destroyed, }}$ and Method B: $\mathrm{COD}_{\text {products }} / \mathrm{COD}_{\text {substrates: }}$ :

Mass balance $A=\frac{\frac{\mathrm{LCH}_{4} \text { out }}{0.35 L . g C O D^{-1}}+\left(g C O D_{\text {substrates }}-g \operatorname{COD}_{\text {digestate }}\right) x 0.08}{\left(\text { gCOD }_{\text {substrates }}-g_{\text {COD }} \text { digestate }\right)} \times 100 \%$

Mass balance $B=\frac{\frac{L C H_{4} \text { out }}{0.35 L . g C O D^{-1}}+\left(g C O D_{\text {substrates }}-g C O D_{\text {digestate }}\right) \times 0.08+g C O D_{\text {digestate }}}{g C O D_{\text {substrates }}} \times 100 \%$

Substrate destruction efficiency was calculated from:

$$
\text { Destr. Eff. }=\left[1-\left(\frac{g C_{D D_{D G}}-g C_{C O D} \text { BA remaining }}{g C O D_{\text {substrate added }}}\right)\right] \cdot 100 \%
$$

$$
g C O D_{\text {substrate added }}=g C O D_{(C B+B B+N P+F P+F W)}
$$


211 Specific methane yield, by period, was calculated from:

$$
\frac{\mathrm{LCH}_{4} \text { produced }}{\mathrm{kgCOD} \text { substrate added }} \text { and } \frac{\mathrm{LCH}_{4} \text { produced }}{\mathrm{kgVS} \text { substrate added }}
$$

213 Synergistic biogas was calculated from:

$$
V_{\text {syn. }}=V_{\text {Total }}-V_{\text {Fibre }}-V_{F W 78}
$$

Where: $\mathrm{V}_{\text {syn. }}$ is the synergistic (or unaccounted for) methane generated from fibre, $\mathrm{V}_{\text {total }}$ is the measured total methane produced; $V_{\text {fibre }}$ is the measured methane produced at $0 \% \mathrm{COD}_{\mathrm{FW}}$, and $\mathrm{V}_{\mathrm{FW}}$ is the

217 calculated maximum volume of methane generated from the added FW alone, from COD FWconverted, assuming $78 \pm 1 \% \mathrm{COD}_{\mathrm{FW}}$ conversion, a value obtained from our biochemical methane potential (BMP) tests (Guilford, 2017) in agreement with the literature (Eleazer et al., 1997).

\section{RESULTS AND DISCUSSION}

222 The results are described and discussed from seven perspectives; 1) analytical results; 2) mass balance;

223 3) long-term performance and stability; 4) the effect of food waste(FW) addition on the digestibility of

224 lignocellulosic fibres, and on performance; 5) the relative digestibility of the fibres - CB, BB, NP, FP and

225 BA - from coupon data; 6) the unexpected effect of a change in bulking agent; and 7) the effect of SRT

226 on performance.

227

\section{$228 \quad 3.1 \quad$ Analytical results for feedstocks, digestate and biogas}

229 The elemental composition and ash content (and thus VS), of each the substrates and digestates, were

230 measured and averaged; the stoichiometric formula of each substrate was calculated (Table S2); the

231 stoichiometric formula of the 83-week weighted average feed to Daisy was also calculated as

$232 \mathrm{C}_{90} \mathrm{H}_{155} \mathrm{O}_{67} \mathrm{~N}$; The COD content of each of the substrates was calculated from Equations (1), (2), (3) and

233 (4), and compared to the measured values (Table S2). The measured and calculated values of COD

234 content corresponded well; unsurprisingly, the greatest discrepancy was for FW, the most variable of 
the substrates. The TS, VS, and COD of the digestate from all 87 LBs was measured (Table S3). The average methane content of the biogas was $58.5 \pm 3.7 \%$ from GM1 (the UASB), and $51.7 \pm 3.6 \%$ from GM2

237 (balance of the system); the weighted average was 52.4\% (Table S4). The methane content was also 238 calculated, from digestion stoichiometry, as 52.5\% (using equations shown in Fig. S3). The measured 239 weekly volume of biogas and of $\mathrm{CH}_{4}$, were corrected to STP (273K and $\left.100 \mathrm{kPa}\right)$ (Table S5).

\subsection{Mass Balance on a COD Basis}

242 Daisy was fed a total of approximately $97 \mathrm{~kg}$ of TS and $125 \mathrm{~kg}$ of COD over 83 weeks, and produced 243 approximately $20,000 \mathrm{~L}$ of $\mathrm{CH}_{4}$ at STP. The mass balance (COD basis) of the entire system was calculated

244 for each period two different ways using equations 6A and 6B, from week 6 to week 88 inclusive (Table 245 S6). The cumulative mass balance for all 83 weeks was $101 \pm 2 \%$ (Method A) and 100 $\pm 2 \%$ (Method B);

246 these results thus validate the sampling and analytical methods used, and create a sound foundation

247 upon which to assess Daisy's performance. The mass balance does show a little variability when 248 considered by individual Period, particularly using Method B (Table S6); the reasons are discussed in the 249 description of Table S6 on page 4 of the SI.

\section{$251 \quad 3.3 \quad$ Long term operation}

252 For each of the 12 operating periods, the feedstock composition, operating conditions, and Daisy's 253 performance measured as substrate destruction efficiency (Equations 7, 8 and 9) and methane yield

254 (Equation 10), are shown in Table 1. The input data to all calculations are derived from Tables S1-S5.

255 The destruction efficiency of BA over 6 weeks averaged about 7\%, irrespective of food waste addition

256 (Table S7). Since BA is to be reused at commercial scale, and would artificially depress measurements of 257 performance, it was excluded from the calculation of substrate destruction efficiency as shown in 258 equations (7), (8), and (9). 
260 The SRT remained at 42 days (i.e., 6 weeks), except during Period 2 (which lasted only 8 weeks) when it was 49 days. Food waste addition, expressed as a percent of total COD added, varied from $17.2 \%$ down to $0 \%$ then back up to $29.3 \%$. The C:N ratio, calculated from Equation 5 (Table 1), ranged between $48: 1$ and 350:1, depending on FW addition, and was always well above the generally accepted stability threshold of 20:1 (Igoni et al., 2008; Wu et al., 2010; Yadvika, 2004). During Period 5, the BA was changed to a different batch which, unexpectedly, reduced digester performance.

Fig. 2 shows the entirety of the experimental period, week by week, expressed as: a) substrate COD in $\mathrm{mg} . \mathrm{L}^{-1} ; \mathrm{d}$ ) recirculating concentration of inorganic salts in $\mathrm{g} . \mathrm{L}^{-1}$; and e) recirculating concentration

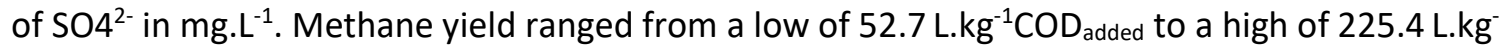

$271{ }^{1} \mathrm{COD}_{\text {added }}$ and the corresponding COD destruction efficiency from $18.6 \%$ to $65.3 \%$ (Fig. $2 \mathrm{~A}$ ). Despite wide

272 variations in methane yield and substrate destruction, Daisy's operation remained stable throughout. In 273 particular, the alkalinity ratio (weekly average) remained below 0.52 (against a target of $\leq 0.4$ ) and the $274 \mathrm{pH}$ between 6.7 and 7.3, with a brief excursion to 7.6 (Fig. 2B). VFA's and sulphate were measured four 275 times per week, beginning at week 35. The first VFA measurement, taken $6 \mathrm{~h}$ after installation of a LB of 276 fresh waste, showed a sharp spike (except at zero FW); the second and third, taken $1 \mathrm{~d}$ and $3 \mathrm{~d}$ later, 277 showed sharp declines (Fig. 2C). At no time was there any indication of a build-up of VFAs, hence the 278 stability of $\mathrm{pH}$ and alkalinity ratio. It was discovered, by about week 20 , that there was no accumulation 279 of leachate within Daisy, and thus no free wastewater being produced. Measurement of the TS content 280 of the digestate revealed that the same quantity of water was being removed in the digestate as was 281 being added in the feed. By measuring the VS content of the leachate it was possible to determine the 282 fate of the inorganic salts; their concentration within Daisy (Fig. 2D) varied with FW addition, falling from 
3.5 g. $\mathrm{L}^{-1}$ in Periods 1,2 and 3 to 2.0 g. $\mathrm{L}^{-1}$ in Period 4c, finally rising to $3.3 \mathrm{~g} . \mathrm{L}^{-1}$ during periods 5 and 6 . The amount of inorganic matter removed in the digestate ( 160g per LB) approximately equaled the amount added in the feed. Up to week 50 , the concentration of sulphate remained close to $50 \mathrm{mg} \cdot \mathrm{L}^{-1}$ but then began to rise as the proportion of FW increased, ultimately reaching $125 \mathrm{mg} \cdot \mathrm{L}^{-1}$ (Fig. 2E).

\subsection{The effect of food waste addition on Daisy's performance - synergy}

One of our main objectives was to study the effects of FW addition on digester performance (Table 1). In took 6 weeks (to change all 6 LBs). With each reduction in $\mathrm{FW}$ addition $\mathrm{CH}_{4}$ production fell, first to 198 substrate destruction efficiency also dropped. At each step, $\mathrm{CH}_{4}$ production attained its new stable level within 3 weeks. It was immediately apparent that the drop in $\mathrm{CH}_{4}$ production could not be accounted for by the reduction in $\mathrm{COD}_{\mathrm{FW}}$ alone. For example, by Period 4c, FW addition had been reduced by 254 gCOD.wk ${ }^{-1}$, equivalent to $89 \mathrm{~L} \mathrm{CH}_{4} \cdot \mathrm{wk}^{-1}$ assuming $100 \% \mathrm{COD}_{\mathrm{Fw}}$ conversion, compared to the measured drop of $214 \mathrm{LCH}_{4} \cdot \mathrm{wk}^{-1}$. This left $125 \mathrm{~L} \mathrm{CH}_{4} \cdot \mathrm{wk}^{-1}$ unaccounted for. The apparent explanation was an unreported effect whereby FW addition enhanced the digestibility of the fibres, and that the extent of enhancement was related to the amount of FW added. The objectives of the research were expanded to include investigation of this apparent synergistic effect. 
switched to BA\#5 for 6 weeks. Performance immediately began to decline (Table 1 and Fig 2A); this was

provisionally attributed to the physical properties of the particular batch of BA, since no other changes

had been made. It took 15 weeks to restore stable $\mathrm{CH}_{4}$ output at $245 \mathrm{~L} . \mathrm{wk}^{-1}\left(169 \mathrm{~L} . k g^{-1} \mathrm{COD}_{\text {added }}\right.$ ) and a less beneficial, and this needs further study.

327 added, but to differing degrees for different fibres (see Section 3.5). The mechanism is not entirely clear,

328 but there are indications that it may be enzymatic. Yuan et. al. (2012) subjected samples of FB to 

for NP requires verification. be reported separately.

digester. A companion microbiological study conducted on samples of leachate, digestate, and food waste from Daisy show clear trends in microbial abundance related to FW addition (Lee, 2018) and will

\subsection{The digestibility of individual fibres and bulking agent}

Not all the fibres are equally digestible and this offers some further insight into the mechanism of synergy. The digestibility of individual fibre samples embedded in the LBs was assessed using coupon tests. Coupons (tea balls) were present under all operating conditions. The destruction efficiency of all four individual fibres $-\mathrm{CB}, \mathrm{BB}, \mathrm{NP}$, and FP plus $\mathrm{BA}$, at the same six $\mathrm{COD}_{\mathrm{FW}}$ addition rates (Table $\mathrm{S7}$ ), are plotted in Fig. 4. It is immediately apparent that their digestibility is ranked $F P>C B>B B>N P>B A$ and this is consistent with the literature (Buffiere et al., 2008; Eleazer et al., 1997; Pommier et al., 2010). It is also apparent that the differences among them grow wider as $\% \mathrm{COD}_{\mathrm{Fw}}$ increases. It would also appear that the digestibility of the fibres may be directly related to the severity of the pulping processes used in their manufacture; FP is chemically pulped and bleached and contains no lignin, CB and BB are also chemically pulped but still contain some lignin (also the latter is coated on one or both sides), NP is mechanically pulped and has a high lignin content, and BA is not pulped at all. 


\subsection{The effect of bulking agent on Daisy's performance}

356 The switch to BA\#5 caused a vexing decline in performance $\left(\mathrm{CH}_{4}\right.$ yield and COD destruction efficiency) of

357 about 20\%. After six weeks (at week 64), leach beds were progressively switched back to BA\#4 (from a reserve supply). Performance gradually improved and, at week 71, the BA was switched again to BA\#6, methane production eventually stabilized at prior levels, and Period 6 began at week 74. BA\#4 and BA\#6 were prepared with a Roto-Chopper (essentially a shredder which produces splinters of wood), and the larger particles screened out; the two batches were similar in appearance and behaviour. BA\#5 was very different; it was produced with a chipper, and the particles were coarser, shorter and fatter (Fig. S2). capacity of BA\#4. The literature shows that digester efficiency is very dependent on maintaining a moisture content of about $80 \%$ in SS-AD (Abbassi-Guendouz et al., 2012; Le Hyaric et al., 2012; Motte et greater role in digestion efficiency than merely ensuring LB permeability. Another possibility is that the chemical composition of BA\#5 was different, perhaps because the wood was greener and recently chipped.

\subsection{Solids retention time}

373 During Period 1 (weeks 6 to 15 ) conditions were kept constant in all respects at $17.2 \% \mathrm{COD}_{\mathrm{FW}}$; stable

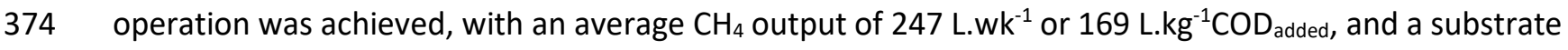
375 destruction efficiency of 53.7\% (Table 1 and Fig. 2A). In Period 2 the SRT was extended to 49d from 42d.

376 This had the effect of creating unevenness in $\mathrm{L} \mathrm{CH}_{4} \cdot \mathrm{wk}^{-1}$, reflected in the increased coefficient of

377 variation (Table 1). Nevertheless, performance remained unchanged at $172 \mathrm{LCH}_{4} \cdot \mathrm{kg}^{-1} \mathrm{COD}_{\text {added, }}$ and COD 378 destruction efficiency of 53.5\%. Extending the SRT to $49 \mathrm{~d}$ was not beneficial. At week 88 , Daisy was shut 
down and the last six LBs removed simultaneously. Substrate destruction efficiency at $29.3 \% \mathrm{COD}_{\mathrm{FW}}$, was determined for all 6 LBs, and plotted against SRT (Fig. 5). Daisy achieved 68.4\% COD destruction at 42d, at which point the curve is almost flat (and presumably close to the asymptote). However, destruction efficiency had already reached $63.5 \%$ at $21 \mathrm{~d}$ and $66.8 \%$ at $28 \mathrm{~d}$. These results suggest that, at $29.3 \% \mathrm{COD}_{\mathrm{FW}}, 98 \%$ of ultimate performance had already been achieved with an SRT of just $28 \mathrm{~d}$. Of necessity, this was a single experiment, but it strongly suggests that the SRT can be significantly reduced with little loss in performance.

\subsection{Comparison to other digesters with similar substrates}

Daisy's performance on a VS basis was compared to that of other digesters with similar substrates,

(Table 2). Three of the comparators were BMP tests (Eleazer et al., 1997; Pommier et al., 2010; Yuan et system (Di Maria et al., 2017). All three BMP studies found the same ranking of fibre digestibility as the present research, $\mathrm{FP}>\mathrm{CB}>\mathrm{BB}>\mathrm{NP}$, and all achieved a higher destruction efficiency and biogas yield than Daisy, but all with longer SRTs of $90 \mathrm{~d}, 60 \mathrm{~d}$ and up to $600 \mathrm{~d}$, respectively. At $29.3 \% C O D_{\mathrm{FW}}$ with an SRT of $\left.62 \% \mathrm{VS}_{\text {destr. }}\right)$. Even at an SRT of 28d, Daisy's performance was virtually undiminished (Fig. 4). Once more, the beneficial effect of FW addition is apparent. Compared to Di Maria et al. (2017), Daisy's performance surpassed that of their LB system, but was slightly inferior to their CSTR. 
of the unexpected effect of FW on the digestibility of fibres. This digester design is simple and relatively

407 potential to operate without the UASB. The rising concentration of sulphate, in response to increased

408 food waste addition, raises questions about the apparent lack or suppression of sulphate reducing

409 bacteria which also requires investigation. The unexpectedly strong performance of Daisy suggests

410 larger scale demonstrations should be undertaken.

\section{ACKNOWLEDGMENTS}

413 This research was funded by the Natural Sciences and Engineering Research Council of Canada

414 (Collaborative Research and Development Grant), and by Miller Waste Systems Inc. We thank Mike

415 Kopansky, John Tomory and Charlie Cassin of Miller Waste Systems for preparing and providing samples,

416 our colleagues at the University of Toronto, Brad Saville, Grant Allen, Savia Gavazza, Paul Jowlabar,

417 Glenn Wilson, Greg Brown and Andy Quaile, for their experience and insights.

\section{SUPPORTING INFORMATION}

420 Detailed description of analytical methods, eight supplementary tables of raw data and calculations, and

421 four supplementary figures showing coupon placement, bulking agent batches and specific methane

422 production. 


\section{REFERENCES (formatted as author-date for review purposes only)}

Abbassi-Guendouz, A., Brockmann, D., Trably, E., Dumas, C., Delgenes, J.P., Steyer, J.P., Escudie, R. 2012. Total solids content drives high solid anaerobic digestion via mass transfer limitation. Bioresource Technology, 111, 55-61.

APHA. 1992. Standard methods for the examination of water and wastewater. 18th ed, American Public Health Association. Washington DC.

Browne, J.D., Allen, E., Murphy, J.D. 2013a. Improving hydrolysis of food waste in a leach bed reactor. Waste Management, 33(11), 2470-2477.

Browne, J.D., Murphy, J.D. 2013b. Assessment of the resource associated with biomethane from food waste. Applied Energy, 104, 170-177.

Browne, J.D., Murphy, J.D. 2014. The impact of increasing organic loading in two phase digestion of food waste. Renewable Energy, 71, 69-76.

Buffiere, P., Frederic, S., Marty, B., Delgenes, J.P. 2008. A comprehensive method for organic matter characterization in solid wastes in view of assessing their anaerobic biodegradability. Water Science and Technology, 58(9), 1783-1788.

City of Ottawa. 2007. ICI and CD Management Options Report: ICI 3Rs Strategy Project. Ottawa.

De Baere, L., Mattheeuws, B. 2013. Anaerobic digestion of the organic fraction of municipal solid waste in Europe - Status, experience and prospects. in: Waste Management, (Eds.) K.J. ThoméKozmiensky, S. Thiel, pp. 517-526.

Di Maria, F., Barratta, M., Bianconi, F., Placidi, P., Passeri, D. 2017. Solid anaerobic digestion batch with liquid digestate recirculation and wet anaerobic digestion of organic waste: Comparison of system performances and identification of microbial guilds. Waste Management, 59, 172-180.

Eleazer, W.E., Odle, W.S., Wang, Y.S., Barlaz, M.A. 1997. Biodegradability of municipal solid waste components in laboratory-scale landfills. Environmental Science \& Technology, 31(3), 911-917.

Environment Canada. 2017. National Inventory Report 1990-2015 Greenhouse Gas Sources and Sinks in Canada, Queen's Printer. Ottawa.

European Union. 1999. European Union Landfill Directive 1999/31/EC, April 26, 1999. European Union Publications Office. .

Forrestal, B.J., Guilford, N.G.H., Poland, R.J. 2006a. Canadian Patent 2,468,158; System and Method for the Production of Biogas and Compost, BioPower Energy Inc. Canada.

Forrestal, B.J., Guilford, N.G.H., Poland, R.J. 2006b. United States Patent 7,101,481; System for the Production of Biogas and Compost from Organic Materials and Method of Operating an Organic Treatment Facility, BioPower Energy Inc. USA.

Government of Canada. 2010. Environment Canada - Report on Waste Management, Environment Canada. Ottawa.

Government of Canada. 2015. State of Waste Management in Canada, Queen's Printer. Ottawa.

Government of Ontario. 2004. Ontario's 60\% Waste Diversion Goal - A Discussion Paper, (Ed.) Ministry of the Environment, Queen's Printer for Ontario. Toronto.

Guilford, N.G.H. 2017. The Anaerobic Digestion of Organic Solid Wastes of Variable Composition. PhD Thesis, Department of Chemical Engineering and Applied Chemistry, University of Toronto. Toronto, pp. 240. https://tspace.library.utoronto.ca/handle/1807/80954

Guilford, N.G.H. 2009. A New technology for the Anaerobic Digestion of Organic Waste. M.Eng thesis, Department of Chemical Engineering and Applied Chemistry, University of Toronto. Toronto, pp. 112. https://tspace.library.utoronto.ca/handle/1807/18314

Hodge, K.L., Levis, J.W., DeCarolis, J.F., Barlaz, M.A. 2016. Systematic Evaluation of Industrial, Commercial, and Institutional Food Waste Management Strategies in the United States. Environmental Science \& Technology, 50(16), 8444-8452. 
Igoni, A.H., Ayotamuno, M.J., Eze, C.L., Ogaji, S.O.T., Probert, S.D. 2008. Designs of anaerobic digesters for producing biogas from municipal solid-waste. Applied Energy, 85(6), 430-438.

Le Hyaric, R., Benbelkacem, H., Bollon, J., Bayard, R., Escudie, R., Buffiere, P. 2012. Influence of moisture content on the specific methanogenic activity of dry mesophilic municipal solid waste digestate. Journal of Chemical Technology and Biotechnology, 87(7), 1032-1035.

Lee, HW. 2018. Microbial Diversity and Abundance in a Sequentially-fed Anaerobic Digester treating Food Waste and Lignocellulosic fibres. MASc thesis, Department of Chemical Engineering and Applied Chemistry, University of Toronto. https://tspace.library.utoronto.ca/handle/1807/89607

Motte, J.C., Escudie, R., Bernet, N., Delgenes, J.P., Steyer, J.P., Dumas, C. 2013. Dynamic effect of total solid content, low substrate/inoculum ratio and particle size on solid-state anaerobic digestion. Bioresource Technology, 144, 141-148.

Murto, M., Bjornsson, L., Rosqvist, H., Bohn, I. 2013. Evaluating the biogas potential of the dry fraction from pretreatment of food waste from households. Waste Management, 33(5), 1282-1289.

Pommier, S., Llamas, A.M., Lefebvre, X. 2010. Analysis of the outcome of shredding pretreatment on the anaerobic biodegradability of paper and cardboard materials. Bioresource Technology, 101(2), 463-468.

Rittmann, B.E., McCarty, P.L. 2001. Environmental Biotechnology: Principles and Applications. McGrawHill.

Satchwel, A.J., Scown, C.D., Smith, S.J., Arnirebrahimi, J., Jin, L., Kirchstetter, T.W., Brown, N.J., Preble, C.V. 2018. Accelerating the Deployment of Anaerobic Digestion to Meet Zero Waste Goals. Environmental Science \& Technology, 52(23), 13663-13669.

$\mathrm{Wu}, \mathrm{X}$., Yao, W.Y., Zhu, J., Miller, C. 2010. Biogas and $\mathrm{CH} 4$ productivity by co-digesting swine manure with three crop residues as an external carbon source. Bioresource Technology, 101(11), 40424047.

Xu, F.Q., Wang, Z.W., Tang, L., Li, Y.B. 2014. A mass diffusion-based interpretation of the effect of total solids content on solid-state anaerobic digestion of cellulosic biomass. Bioresource Technology, $167,178-185$.

Yadvika, S., T.R. Sreekrishnan, Sangeeta Kohli, Vineet Rana. 2004. Enhancement of biogas production from solid substrates using different techniques. Bioresource Technology, 95, 1-10.

Yuan, X.F., Cao, Y.Z., Li, J.J., Wen, B.T., Zhu, W.B., Wang, X.F., Cui, Z.J. 2012. Effect of pretreatment by a microbial consortium on methane production of waste paper and cardboard. Bioresource Technology, 118, 281-288.

Yuan, X.F., Wen, B.T., Ma, X.G., Zhu, W.B., Wang, X.F., Chen, S.J., Cui, Z.J. 2014. Enhancing the anaerobic digestion of lignocellulose of municipal solid waste using a microbial pretreatment method. Bioresource Technology, 154, 1-9.

Zhang, B., He, P.J., Lu, F., Shao, L.M., Wang, P. 2007. Extracellular enzyme activities during regulated hydrolysis of high-solid organic wastes. Water Research, 41(19), 4468-4478.

Zhang, Y., Banks, C.J., Heaven, S. 2012. Anaerobic digestion of two biodegradable municipal waste streams. Journal of Environmental Management, 104, 166-174. 
bioRxiv preprint doi: https://doi.org/10.1101/564203; this version posted February 28, 2019. The copyright holder for this preprint (which was not certified by peer review) is the author/funder, who has granted bioRxiv a license to display the preprint in perpetuity. It is made available under aCC-BY-NC-ND 4.0 International license.

\section{TABLES}

Table 1. Operating conditions, substrate destruction efficiency as VS and COD, and $\mathrm{CH}_{4}$ yield, all by Period

\begin{tabular}{|c|c|c|c|c|c|c|c|c|c|c|c|c|c|c|}
\hline \multirow[b]{3}{*}{ Period } & \multirow[b]{3}{*}{ Weeks } & \multirow[b]{3}{*}{$\begin{array}{c}\text { BA } \\
\text { Batch }\end{array}$} & \multicolumn{6}{|c|}{ Operating Conditions } & \multicolumn{2}{|c|}{$\begin{array}{l}\text { \% Substrate } \\
\text { Destruction }\end{array}$} & \multicolumn{4}{|c|}{$\mathrm{CH}_{4}$ production } \\
\hline & & & \multicolumn{3}{|c|}{$\mathrm{gCOD}_{\text {added }} / \mathrm{LB}$} & \multirow[b]{2}{*}{$\begin{array}{c}{ }^{b} \mathrm{COD}_{\mathrm{FW}} \\
\%\end{array}$} & \multirow[b]{2}{*}{$\begin{array}{l}{ }^{\mathrm{C}} \mathrm{C}: \mathrm{N} \\
\text { ratio }\end{array}$} & \multirow[b]{2}{*}{$\begin{array}{l}\text { SRT } \\
\text { days }\end{array}$} & \multirow[b]{2}{*}{ VS } & \multirow[b]{2}{*}{ COD } & \multirow[b]{2}{*}{ L. $w^{-1}$} & \multirow[b]{2}{*}{$n$} & \multirow[b]{2}{*}{$\begin{array}{l}\text { L.kg-1 } \\
\text { VS added }\end{array}$} & \multirow[b]{2}{*}{$\begin{array}{l}\text { L...kg-1 } \\
\text { CODadde }\end{array}$} \\
\hline & & & BA & ${ }^{a} \mathrm{FB}$ & FW & & & & & & & & & \\
\hline 1 & $6-15$ & 1 & 645 & 1200 & 250 & 17.2 & 74 & 42 & 57.3 & 53.7 & $247 \pm 7$ & 10 & 219 & 169 \\
\hline $2^{d}$ & $16-24$ & 2 & 645 & 1200 & 250 & 17.2 & 74 & 49 & 58.2 & 53.5 & $197 \pm 26$ & 9 & 223 & 172 \\
\hline 3 & $26-31$ & $2 \& 3$ & 645 & 1200 & 250 & 17.2 & 74 & 42 & 59.3 & 54.2 & $278 \pm 18$ & 5 & 239 & 185 \\
\hline $4 a$ & $32-37$ & 4 & 645 & 1200 & 178 & 12.9 & 93 & 42 & 43.2 & 38.9 & $198 \pm 5$ & 5 & 184 & 143 \\
\hline $4 \mathrm{~b}$ & $38-44$ & 4 & 645 & 1200 & 104 & 7.9 & 130 & 42 & 33.2 & 31.8 & $138 \pm 3$ & 4 & 135 & 105 \\
\hline $4 c$ & $44-49$ & 4 & 645 & 1200 & 0 & 0.0 & 350 & 42 & 20.0 & 18.6 & $63 \pm 4$ & 4 & 67 & 52.7 \\
\hline $5 a$ & $50-57$ & 4 & 645 & 1200 & 250 & 17.2 & 74 & 42 & 53.1 & 51.7 & $217 \pm 21$ & 6 & 210 & 162 \\
\hline $5 b$ & $58-63$ & 5 & 645 & 1200 & 250 & 17.2 & 74 & 42 & 45.9 & 43.8 & $251 \pm 26$ & 6 & 217 & 168 \\
\hline $5 c$ & $64-70$ & 4 & 645 & 1200 & 250 & 17.2 & 74 & 42 & 48.7 & 43.9 & $218 \pm 16$ & 6 & 200 & 154 \\
\hline $5 d$ & $71-74$ & 6 & 645 & 1200 & 250 & 17.2 & 74 & 42 & 56.3 & 53.0 & $245 \pm 19$ & 5 & 219 & 169 \\
\hline $6 a$ & $74-80$ & 6 & 645 & 1200 & 333 & 21.7 & 62 & 42 & 63.5 & 56.0 & $297 \pm 12$ & 6 & 246 & 189 \\
\hline $6 b$ & $81-88$ & 6 & 645 & 1200 & 500 & 29.3 & 48 & 42 & 69.4 & 65.3 & $384 \pm 8$ & 6 & 296 & 225 \\
\hline
\end{tabular}

${ }^{a}$ gCOD ${ }_{F B}$ comprises $\mathrm{CB}=482, \mathrm{BB}=380, \mathrm{NP}=142$ and FP $=196 ;{ }^{\mathrm{b}}$ Calculated as percent of $\mathrm{FB}+\mathrm{FW}$ (without BA). ${ }^{\mathrm{C} C a l c u l a t e d}$ as a weighted avg. from elemental analysis (Table S2) ${ }^{d}$ Seven week SRT achieved by twice skipping a LB replacement at the seventh week, over a total of 9 weeks; substrate destruction efficiency unchanged; 7 weeks of methane production spread over 9 weeks to give an effective yield = $197 * 9 / 7=253$ L.wk ${ }^{-1}$; cf Period 1. 
Table 2. Daisy's performance compared to that of other digesters fed with similar substrates

\begin{tabular}{|c|c|c|c|c|c|c|}
\hline Data Source & $\begin{array}{l}\text { Reactor Design and } \\
\text { Operation }\end{array}$ & Substrates(s) & SRT (d) & $\operatorname{COD}_{\mathrm{Fw}} \%$ & $\begin{array}{l}\text { Methane yield } \mathrm{mLCH}_{4} . \\
\qquad \mathrm{g}^{-1} \mathrm{VS}_{\text {added }}\end{array}$ & $\begin{array}{c}\text { Percent } \\
\text { destruction } \\
\text { efficiency } \\
\text { as VS }\end{array}$ \\
\hline \multirow[t]{6}{*}{$\begin{array}{l}\text { Daisy } \\
\text { (this study) }\end{array}$} & Sequentially-fed leach beds & \multirow{6}{*}{$\begin{array}{l}\mathrm{CB}+\mathrm{BB}+\mathrm{FP}+\mathrm{NP} \\
\text { plus } \mathrm{FW}\end{array}$} & \multirow{6}{*}{42} & 0 & 66.8 & 20.0 \\
\hline & plus UASB & & & 7.9 & 134.8 & 33.2 \\
\hline & 6 LBs 50 L total & & & 12.9 & 184.4 & 43.2 \\
\hline & UASB 27L & & & 17.2 & 218.7 & 56.3 \\
\hline & \multirow[t]{2}{*}{2 Tanks $35 \mathrm{~L}$ total } & & & 21.7 & 246.0 & 63.5 \\
\hline & & & & 29.3 & 296.3 & 69.4 \\
\hline $\begin{array}{l}\text { Pommier et al. } \\
\text { (2010) }\end{array}$ & $\begin{array}{l}\text { BMP tests, six grams of } \\
\text { substrate }\end{array}$ & $\begin{array}{c}\mathrm{CB}+\mathrm{BB}+\mathrm{NP}+\mathrm{FP}+ \\
\text { magazines }\end{array}$ & 90 & & 149.6 & 42.0 \\
\hline \multirow[t]{2}{*}{$\begin{array}{l}\text { Yuan et al. } \\
(2012,2014)\end{array}$} & $\begin{array}{l}\text { BMP tests: with microbial } \\
\text { pre-treatment }\end{array}$ & \multirow{2}{*}{$\mathrm{CB}+\mathrm{FP}+\mathrm{NP}$} & \multirow{2}{*}{60} & & 92.9 & N/A \\
\hline & $\begin{array}{l}\text { BMP tests: no microbial } \\
\text { pre-treatment }\end{array}$ & & & & 209.0 & N/A \\
\hline \multirow[t]{5}{*}{$\begin{array}{l}\text { Eleazer et al. } \\
\text { (1997) }\end{array}$} & BMP + daily leachate recirc. & FW & \multirow{5}{*}{600} & & 320.6 & 77.4 \\
\hline & \multirow[t]{4}{*}{$2 \mathrm{~L}$ reactors } & NP & & & 75.4 & 31.1 \\
\hline & & $\mathrm{CB}$ & & & 155.0 & 54.4 \\
\hline & & FP & & & 288.0 & 54.6 \\
\hline & & MSW & & & 122.3 & 58.4 \\
\hline $\begin{array}{l}\text { Zhang et al. } \\
\text { (2012) }\end{array}$ & CSTR semi-cont. feed $35 \mathrm{~L}$ & mr-OFMSW & 30 & & 304.0 & 62.0 \\
\hline \multirow{2}{*}{$\begin{array}{l}\text { Di Maria et al. } \\
\text { (2017) }\end{array}$} & CSTR - 100L & \multirow{2}{*}{ OFMSW } & \multirow{2}{*}{30} & & 320.0 & N/A \\
\hline & Leach bed - 100L & & & & 252.0 & N/A \\
\hline
\end{tabular}

$\mathrm{CB}=$ cardboard, $\mathrm{BB}=$ boxboard, $\mathrm{FP}=$ fine paper, $\mathrm{NP}=$ newsprint, $\mathrm{FW}=$ food waste, OFMSW = organic fraction of municipal solid waste, mr-OFMSW = mechanically recovered OFMSW. N/A = not available 
bioRxiv preprint doi: https://doi.org/10.1101/564203; this version posted February 28,2019 . The copyright holder for this preprint (which was not certified by peer review) is the author/funder, who has granted bioRxiv a license to display the preprint in perpetuity. It is made available under aCC-BY-NC-ND 4.0 International license.

\section{FIGURES}

A

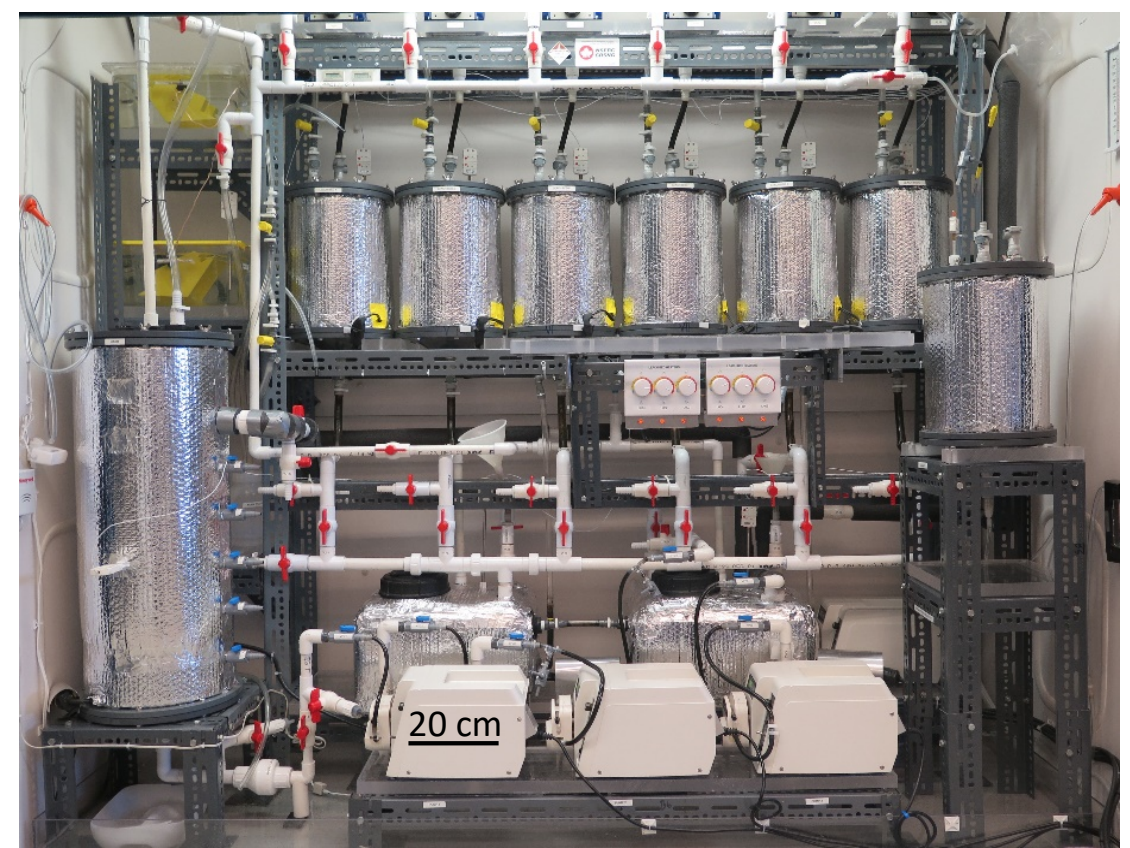

B

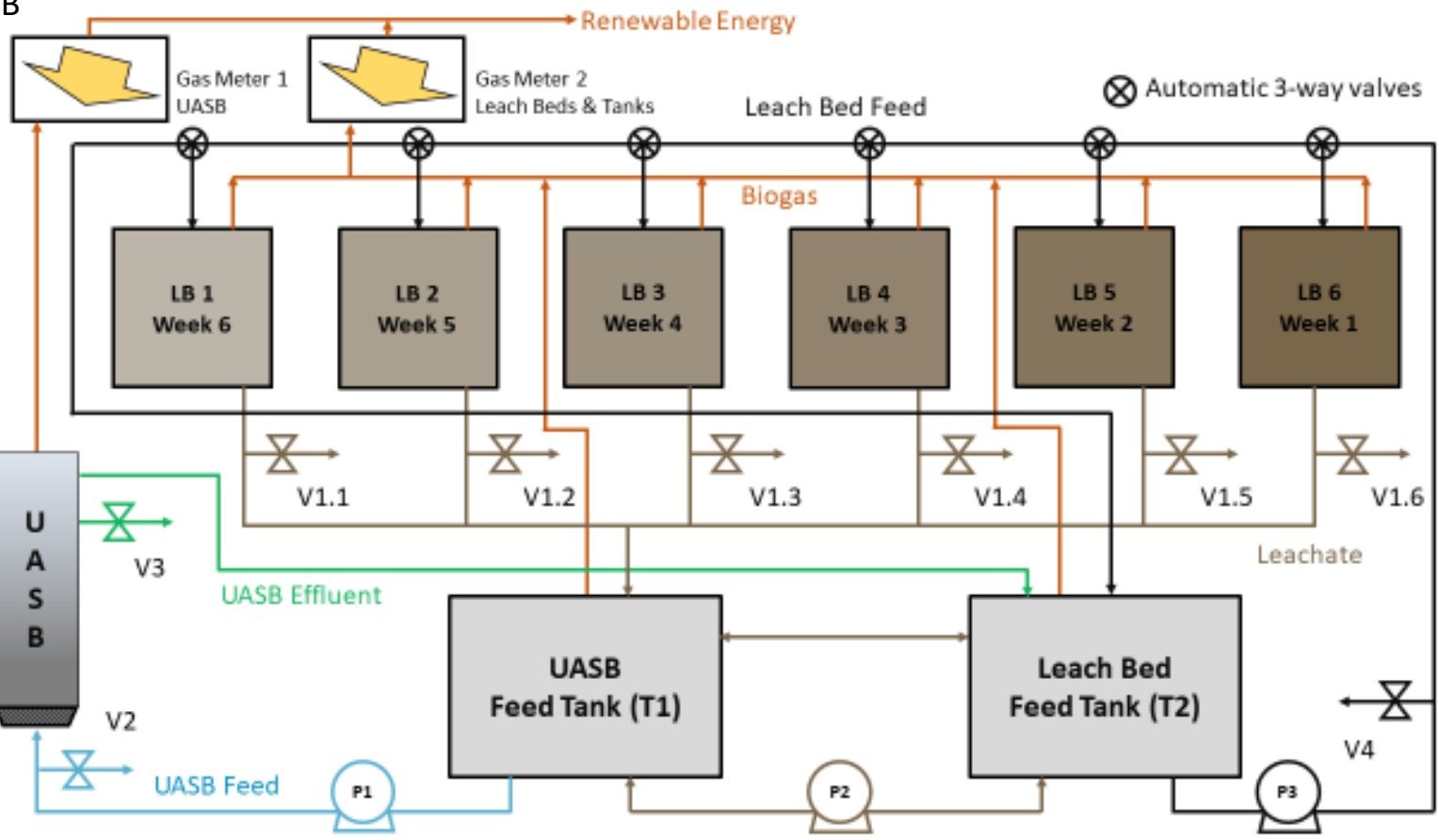

Fig. 1: Daisy the Digester. A. Photograph; B. Schematic process flow diagram; 6 LBs fed sequentially at 1 wk. intervals; one UASB; 2 leachate tanks - T1 to feed UASB, and T2 to feed LBs; 3 peristaltic pumps - P3 feeding LBs, P1 feeding UASB, P2 balancing T1 and T2; two wet-tip gas meters, 6 automatic 3-way valves and 9 sampling valves. 
bioRxiv preprint doi: https://doi.org/10.1101/564203; this version posted February 28,2019 . The copyright holder for this preprint (which was not certified by peer review) is the author/funder, who has granted bioRxiv a license to display the preprint in perpetuity. It is made available under aCC-BY-NC-ND 4.0 International license.

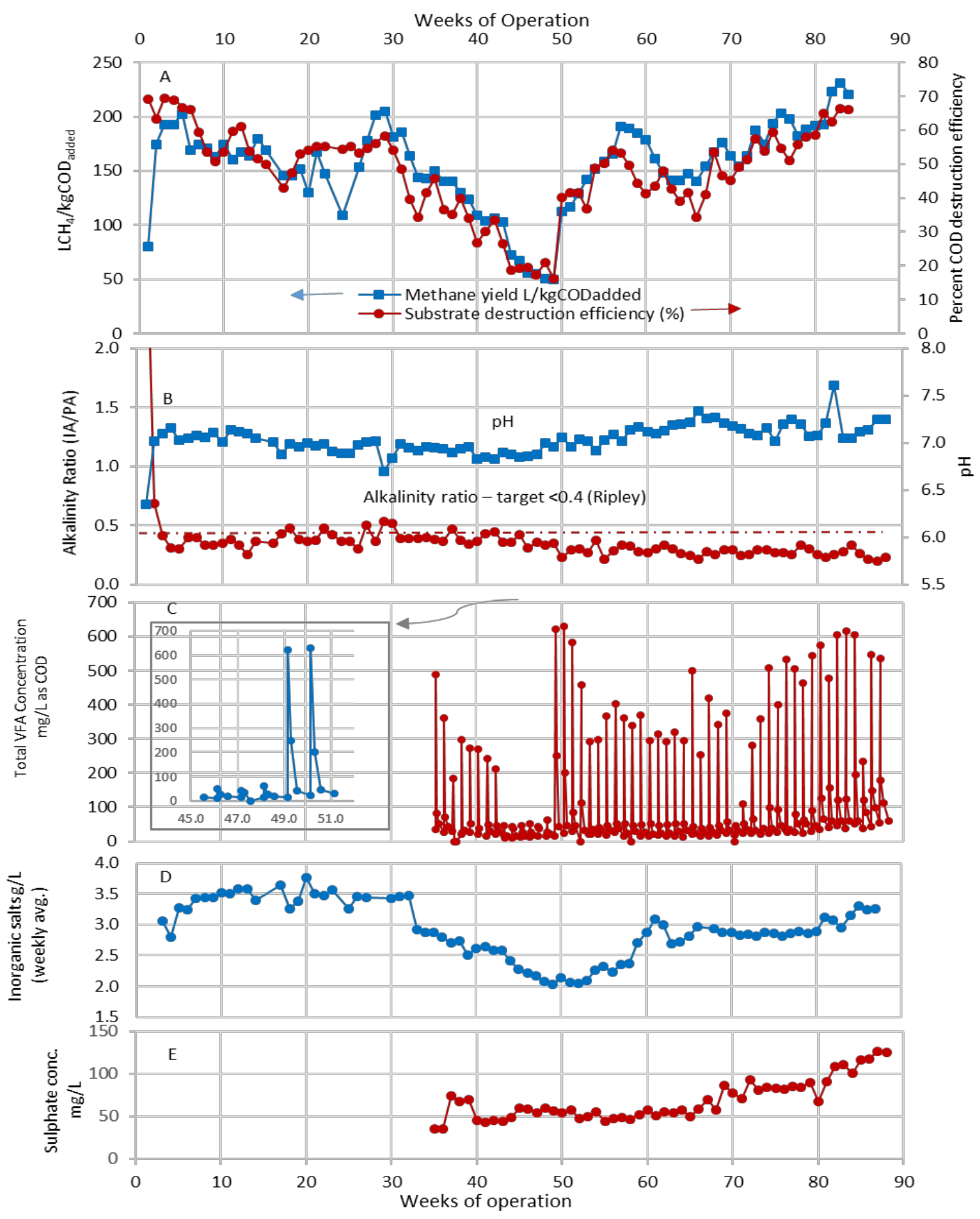

Fig. 2: Daisy's performance vs. time. A) weekly methane production ( $\left.L / \mathrm{kgCOD}_{\text {added }}\right)$; substrate COD destr. eff. (\%); B) alkalinity ratio (wkly avg.) - ideal ratio $<0.4$, and $\mathrm{pH}$ : D) total VFAs, acetate + propionate + butyrate, ( $\mathrm{mg} / \mathrm{L}$ as COD, $4 \mathrm{x}$ wkly); C) conc. of recirc. inorganic salts (g/L, wkly avg.); E) conc. of recirc. sulphate (g/L, wkly avg). 


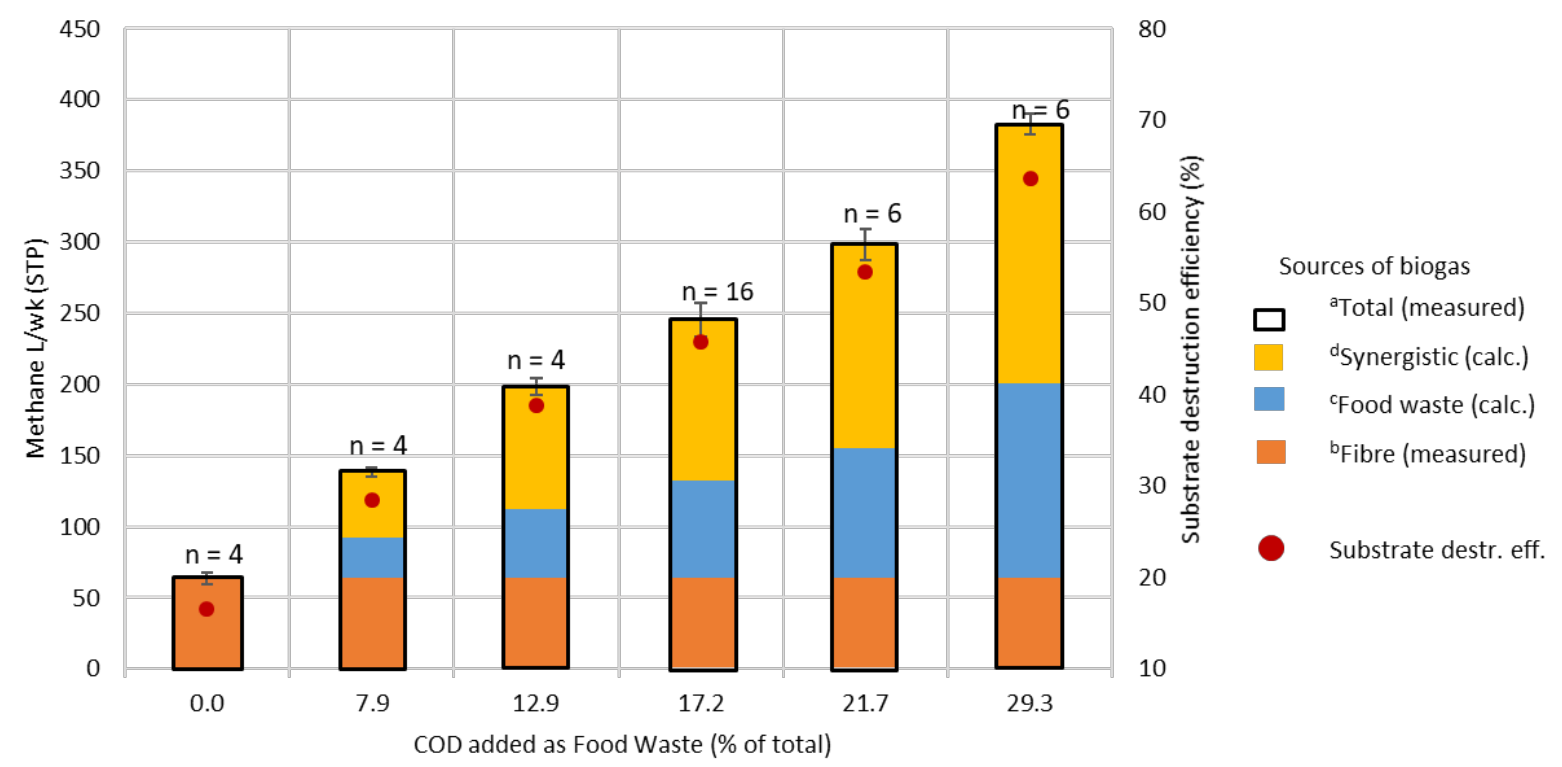

Fig. 3: The effect of food waste addition on methane production (bars) and substrate destruction efficiency (red dots). ${ }^{\mathrm{a}}$ Total measured vol. $\mathrm{CH}_{4}\left(\mathrm{~L}\right.$.wk ${ }^{-1}$ ); ${ }^{\mathrm{b}}$ measured vol. $\mathrm{CH}_{4}$ from FB alone (no FW); ${ }^{\mathrm{c}}$ calculated vol. $\mathrm{CH}_{4}$ from FW added assuming $78 \%$ COD conversion; ${ }^{d}$ synergistic biogas from FB as a result of FW addition calculated by difference. All vol. in L.wk ${ }^{-1}$ at STP; methane at $52.4 \%$ of biogas and assumed $78 \% \mathrm{COD}_{\mathrm{FW}}$ conv. was determined from BMP tests. (see also Figure $\mathrm{S} 4$ )

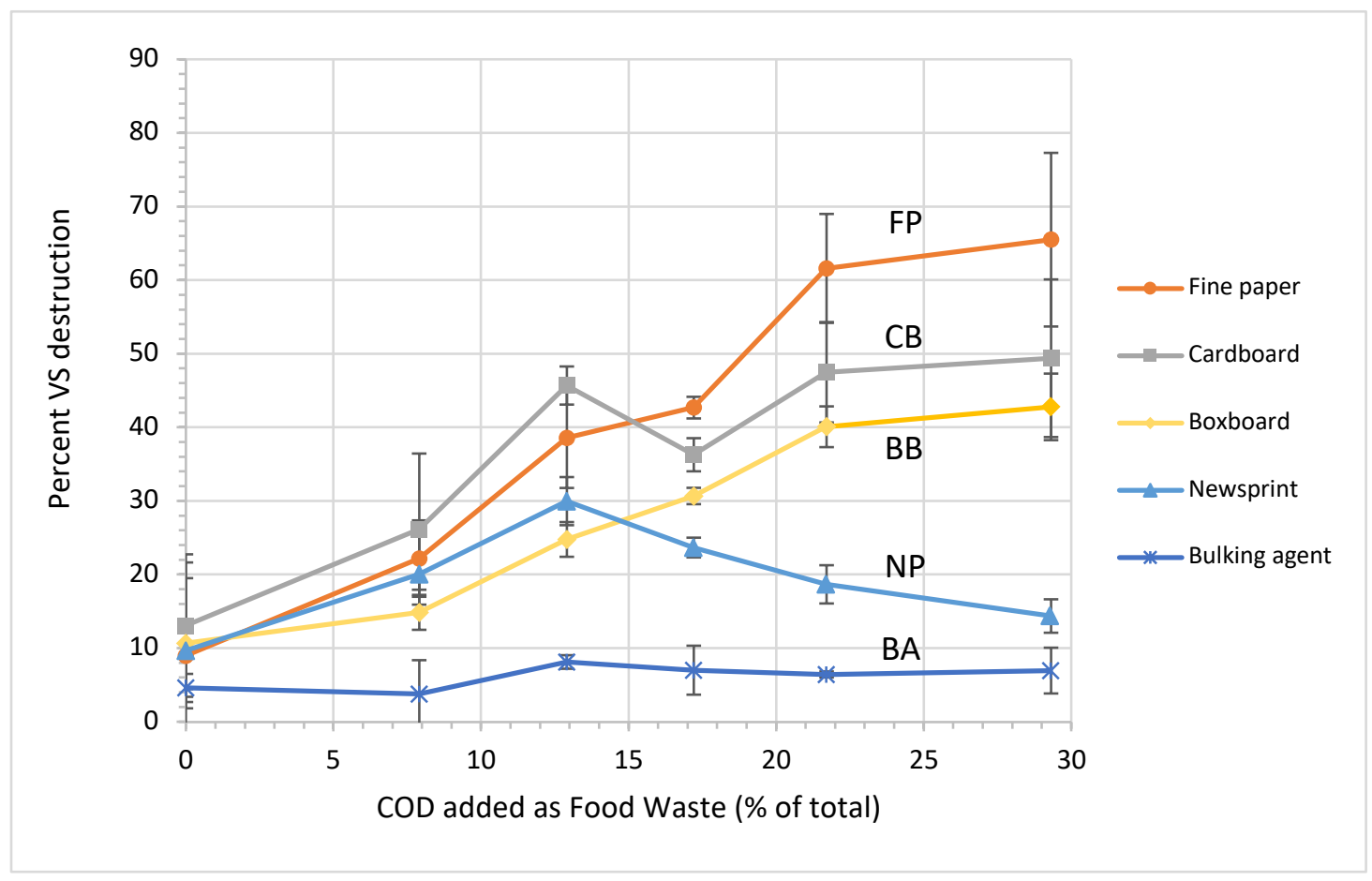

Fig. 4: Destruction efficiency of individual FB samples within Daisy vs. FW addition rate based on data from coupon tests. Shows ranking of digestibility $\mathrm{FP}>\mathrm{CB}>\mathrm{BB}>\mathrm{NP}>\mathrm{BA}$ and effect of $\% \mathrm{COD}_{\mathrm{FW}}$; note absence of $\mathrm{FW}$ effect on $\mathrm{BA}$. 
bioRxiv preprint doi: https://doi.org/10.1101/564203; this version posted February 28, 2019. The copyright holder for this preprint (which was not certified by peer review) is the author/funder, who has granted bioRxiv a license to display the preprint in perpetuity. It is made available under aCC-BY-NC-ND 4.0 International license.

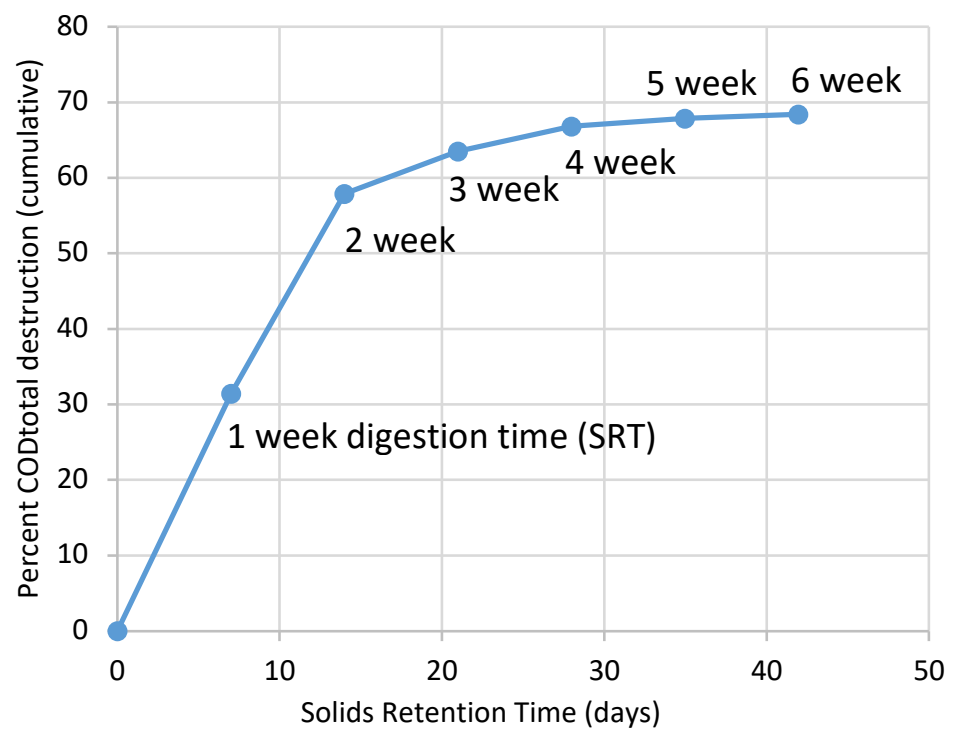

Fig. 5: COD Destruction vs Digestion Time at 29\%CODFw. Data from final week 88 when 6 LBs removed simultaneously (each with a different SRT). 